\title{
HUKUM SEBAGAI SISTEM NORMA
}

\author{
Oleh : \\ Diah Aju Wisnu Wardhani*
}

\begin{abstract}
Talking about law as the system means that we are talking about law as a system of norm. As a system of norm, the creation of positive law should obey higher norms, so that a system of law is a leader of the principle of law pyramidally. Hopefully, referring to a law as a system of norm, the positive law may functional in the life of society.
\end{abstract}

Kata Kunci: Sistem hukum, norma hukum

\section{PENDAHULUAN}

Agar tatanan kehidupan manusia dapat berjalan dengan baik dan harmonis, tanpa ada yang merasa dirugikan mau tidak mau harus ada aturan yang mengaturnya yaitu hukum. Malahan lebih jauh lagi, sejalan dengan dinamika perkembangan dan tuntutan hidup dan kehidupan manusia itu sendiri, ternyata hukum tidak hanya sekedar tatanan aturan, tatapi hukum sudah dijadikan sebagai sarana atau alat dalam upaya meningkatkan kesejahteraan masyarakat itu sendiri. Dengan kata lain, hukum tidak hanya sebagai suatu sistem norma, tetapi hukum telah menjadi

- Dosen Fakultas Hukum Universitas Merdeka Malang, sekarang sedang menyelesaikan program Doktor Ilmu Hukum pada program Pascasarjana Fakultas Hukum Universitas Brawijaya Malang "tools" bagi penguasa untuk menentukan arah kebijakan yang akan dijalankannya.

Pada tataran hukum sebagaimana dimaksud di atas, hukum bukan lagi sebagai norma yang bebas nilai, tetapi hukum sangat sarat dengan berbagai kepentingan, terutama kepentingan para penguasa itu sendiri. Kenyataan ini amat bertentangan dengan teori hukum murni Hans Kelsen yang menegaskan bahwa hukum harus dibebaskan dari anasiranasir non-hukum. ${ }^{1}$ Namun demikian, fakta empiris ini harus disikapi, dalam upaya bagaimana agar hukum bisa fungsional ditengah-tengah kehidupan masyarakat.

\footnotetext{
${ }^{1}$ Lebih lanjut tentang tentang teori hukum murni pada Hans Kelsen, Pure Theory of Law, Berkely: University California Press 1978, halaman 1-2.,
} 
Mengingat hukum merupakan ekspresi dari kesadaran hukum rakyat (volksgeits) sebagaimana dimaksudkan oleh Frederick Karl von Savigny. Kondisi ini, hanya bisa kita terapkan pada masyarakat yang masih sederhana. Permasalahannya sekarang adalah kita hidup pada masyarakat "modern", di mana kebutuhan akan hukum itu amat kompleks, hukum tidak hanya berfungsi sebagai "rules", tetapi hukum harus mampu memenuhi kebutuhan masyarakat itu sendiri. Di sini hukum harus mampu berfungsi sebagai pencerminan kehendak manusia tentang bagaimana seharusnya masyarakat itu dibina dan ke mana harus diarahkan. ${ }^{2}$ Di sini hukum telah dijadikan sebagai sarana rekayasa sosial yang oleh Roescou Pound disebut dengan "law as a tool social enggenering".

Namun demikian harus disadari bahwa dengan sedemikian kompleksnya tuntutan masyarakat modern terhadap hukum pada satu sisi, dan pada sisi lain adanya keinginan penguasa (political will) untuk membina dan mengarahkan warganya sesuai dengan. Kedua sisi ini berada pada posisi yang saling berhadapan, sehingga sulit untuk menyatukannya. Hal ini terbukti dari pelaksanaan politik pembangunan hukum pada masa rezim Orde Baru, di mana terjadinya rekayasa sosial (social enggenering) dengan mengedepankan hukum sebagai dasarnya ternyata tidak berhasil, yang terjadi justru pemarjinalan hakhak masyarakat itu sendiri. Apa lagi kalau kita bawa ke era globalisasi sekarang ini justru yang mengedepan adalah tesis yang menyatakan bahwa hukum itu tertatah tatih dalam upaya mengikuti dan memenuhi tuntutan masyarakat (het recht hinkt achter de feiten aan).

Berkaitan dengan deskripsi tersebut di atas, ada beberapa permasalahan yang perlu menjadi sorotan yaitu sebagai berikut :

\footnotetext{
${ }^{2}$ Esmi Warasih, Lot., cit., halaman, 21.
}

Pertama; tujuan apa yang hendak diwujudkan hukum? Kedua; fungsi apa saja yang dapat dilakukan oleh hukum? Ketiga; bagaimana fungsi hukum itu dijalankan dalam kaitannya dengan sistem norma?

\section{PENGERTIAN TENTANG HUKUM}

Sebelum membahas lebih jauh tentang ketiga permasalahan sebagaimana dimaksud di atas, perlu kiranya dipahami lebih dahulu apa yang dimaksud dengan "hukum" dan "norma" itu sendiri. Berpijak dari pengertian tersebut baru bisa diketahui hukum sebagai norma dan fungsinya dalam tatanan kehidupan masyarakat modern.

Hukum pada hakikatnya merupakan sesuatu yang bersifat abstrak, meskipun dalam manifestasinya bisa berwujud konkret, namun untuk menjawab pertanyaan apakah hukum itu maka kita dihadapkan pada kesulitan untuk menjelaskannya. Semua itu tidak terlepas dari fakta bahwa hukum itu amat luas ruang lingkupnya, mencakup seluruh tatanan kehidupan masyarakat. Hal sejalan dengan apa yang diungkapkan oleh Emmanuel Kant beberapa abad yang silam dengan ungkapan bahwa tidak seorang pun hakim yang mampu membuat definisi hukum yang tepat (noch suchen die juristen eine definition zu ihrem begriffe von recht). ${ }^{3}$ Kemudian Lloyd menegaskan bahwa ".... although 'much juristic ink' has been used in an attemp to provide 'a universally acceptable definition of law', there is little sigi of the objective having been attained"."

Meskipun secara normatif maupun dogmatik dapat dikatakan bahwa hukum mengatur seluruh segi kehidupan manusia,

${ }^{3}$ Achmad Ali, Menguak Tabir Hukum (Suatu Kajian Filosofis dan Sosiologis), Toko Gunung Agung, Jakarta, 2002, halaman 10.

4 Lebih lanjut lihat dalam Curzon, L.B, Jurisprudence, $M$ \& E Handbook, 1979, page 24-28. 
mulai dari kandungan sampai ia meninggal dunia. Namun dalam kenyataan tidak seluruh segi kehidupan manusia yang diatur dan diselesaikan oleh hukum. ${ }^{5} \mathrm{Hal}$ ini tidak terlepas dari begitu luasnya cakupan yang harus diatur oleh hukum itu sendiri, sehingga pada bidang-bidang tertentu justru hukum tidak mampu mengaturnya.

Sebagai pegangan dapat kita lihat beberapa rumusan dari pengertian hukum yang disampaikan oleh para ahli. Namun demikian rumusan yang disampaikan itu amat tergantung dari aliran atau paham yang mereka anut di antaranya adalah sebagai berikut : ${ }^{6}$

\section{A. Paham Sosiologis}

Roscoe Pound mendefinisikan hukum sebagai berikut yaitu "Law in the sence of the legal order has for its subject relation of individual human beings with each other and the conduct of individuals so far as they affect orthers or affect the social or economic order. Law in the sence of the body of authoritative grounds of .....judicial decision and administrative action has for its subject matter the expectation or claims or wants held or asserted by individual human beings or groups of human beings which affect their relations or determine their counduct".

Dari rumusan di atas terlihat bahwa Pound membedakan hukum dalam 2 (dua) arti yaitu :

1. Hukum dalam arti sebagai tata hukum yaitu berkaitan dengan :

a. Hubungan antara manusia dengan individu lainnya dan,

b. Tingkah laku para individu yang mempengaruhi individu lainnya atau yang mempengaruhi tata sosial, atau mempengaruhi tata ekonomi.

2. Sedangkan hukum dalam arti selaku kumpulan dasar-dasar kewenangan dari putusan-putusan pengadilan dan tindakan administratif.

Jadi Pound menekankan bahwa hukum merupakan realitas sosial.

B. Paham Realis

- Holmes menegaskan bahwa hukum adalah "The propheeies of what the court will do.....are what I mean by the law".

- Salmond menyatakan "The law may be defined as the body of principle recognised and acted on by the courts of justice".

Dari kedua pakar realisme Amerika ini terlihat bahwa hukum diidentikkan pengadilan dan hakim.

C. Paham Antropologi

- Paul Bohannan menegaskan bahwa "Law is that body of binding obligations which has been reinstitutionalised within the legal institution".

- Puspisil menyatakan bahwa "Law is rules or modes of conduct made obligatory by some sanction which is imposed and enforced for their violation by $a$ controlling outhority".

D. Paham Positivis dan dogmatik

- Jonh Austin menyatakan bahwa "Law is command set, either directly or circuitously, by a sovereign individual or body, to a member or members of some independent political society in which his authority is suupreme".

- Blackstone menyatakan bahwa "Law is rule of action prescribed or dictated ha some superior which some interior is bound to obey".

Dilihat dari sumber otoritasnya, maka kedua rumusan hukum dari paham positivis ini lebih mengacu pada perintah dan tindakan dari

\footnotetext{
s Achmad Ali, Lot., cit., halaman 11.

${ }^{6}$ Ibid., halaman 18-36.
} 
penguasa terhadap mereka yang berada di bawah penguasaannya.

\section{E. Berdasarkan Kamus}

- Oxford English Dictionary menegaskan bahwa "Law is the body of rules, whether formally enacted or customary, which a state or community recognises as binding on members or subjects".

- Cassell's Dictionary menegaskan bahwa "Las is a rule of conduct imposed by authority or accepted by the community as binding".

Dari berbagai pengertian tersebut di atas, sangat jelas sekali bahwa definisi hukum yang mereka rumuskan amat tergantung dari sudut pandang dan paham yang mereka anut, sehingga untuk dapat merumuskan suatu pengertian hukum yang memuaskan sangat sulit, atau tidak akan pernah bisa sama sekali, karena hukum itu begitu luas dan banyak segi kehidupan yang diaturnya. Hal ini senada dengan ungkapan Lemaire yang mengatakan bahwa hukum itu banyak seginya serta meliputi segala lapangan kehidupan manusia yang menyebabkan orang tidak mungkin membuat suatu definisi hukum yang memadai dan komprehensif. Demikian pula halnya apa yang dinyatakan Kisch bahwa oleh karena hukum itu tidak dapat dilihat atau ditangkap oleh panca indra, maka sukarlah untuk membuat suatu definisi tentang hukum yang memuaskan umum. $^{\text {? }}$

Untuk itu Sudikno Mertokusumo merumuskan hukum secara umum yaitu keseluruhan peraturan atau kaidah dalam kehidupan bersama; keseluruhan tentang tingkah laku yang berlaku dalam suatu kehidupan bersama, yang dapat dipaksakan pelaksanaannya dengan suatu sanksi. ${ }^{8}$

\footnotetext{
${ }^{7}$ Van Apeldorn, Pengantar Ilmu Hukum, Jakarta, 1983, halaman 13.
}

Kemudian Satjipto Rahardjo membuat suatu pengertian hukum yang didasarkan pada 3 (tiga) sudut pandang yaitu : ${ }^{9}$

1. Hukum dipandang sebagai perwujudan dari nilai-nilai tertentu yang lebih bersifat idealis. Dalam hal ini kita akan dihadapkan dengan pandangan yang bersifat filosofis seperti lahirnya pertanyaan apa itu keadilan?

2. Hukum dipandang sebagai suatu sistem peraturan-peraturan yang abstrak. Dalam hal ini perhatian akan terfokus pada hukum sebagai suatu lembaga yang benar-benar otonom, yaitu bisa dibicarakan sebagai subyek tersendiri yang terlepas dari hal-hal di luar peraturan-peraturan tersebut. Sedangkan metode yang dipakai lebih bersifat normatif-analitis.

3. Hukum sebagai alat untuk mengatur masyarakat, dalam hal ini metode pendekatan jatuh pada penggunaan metode sosiologis. Pada paham ketiga ini hukum dikaitkan dengan usaha untuk mencapai tujuan serta memenuhi kebutuhan konkret dalam masyarakat. Metode sosiologis ini lebih memfokuskan pengamatannya terhadap efektivitas dari hukum.

\section{TUJUAN HUKUM}

Dari berbagai pengertian hukum sebagaimana disebutkan oleh para pakar tersebut di atas, dibalik pengertian itu secara implisit mengandung tujuan yang hendak dicapai oleh hukum itu sendiri. Perlu dipahami bahwa hukum adalah alat, bukanlah tujuan. Yang mempunyai tujuan adalah manusia. Akan tetapi manusia adalah zoon politicon, maka dengan

${ }^{8}$ Sudikno Mertokusumo, Mengenal Hukum Suatu Pengatar, Liberti, Yogyakarta, 1968, halaman 37.

${ }^{9}$ Dalam Esmi Warasi, Pranata Hukum, Op., cit., halaman 23. Lebih lanjut lihat Satjipto Rahardjo, Ilmu Hukum, Alumni, Bandung, 1986, halaman 56. 
seorang pun dapat diperlakukan secara sewenang-wenang. ${ }^{14}$

6. Keadilan Legalis adalah keadilan yang ingin diciptakan oleh undang-undang.

Pakar hukum Indonesia Mochtar Kusumaatmadja dan Arief Sidharta menegaskan bahwa "tujuan hukum tidak bisa dilepaskan dari tujuan akhir dari hidup bermasyarakat yang tidak dapat dilepaskan dari nilai-nilai dan falsafah hidup yang menjadi dasar hidup masyarakat itu, yang akhirnya bermuara pada keadilan", ${ }^{15}$

\section{B. Teori Utilitas}

Jeremy Bentham dalam bukunya Introduction to The Principle of Morals and Legislation menegaskan bahwa tujuan hukum adalah untuk mewujudkan apa yang bermanfaat atau yang sesuai dengan daya guna (efektive), sehingga ajarannya ini disebut juga dengan "utilitarisme" atau ada juga menyebut dengan "eudaemonisme". Dalam ajarannya ini ada suatu adagiumnya yang menyatakan "The greatest happiness for the greatest number" (kebahagiaan yang terbesar untuk jumlah yang terbanyak). ${ }^{16}$ Pernyataan itu mengandung makna bahwa hukum yang baik adalah hukum yang memberikan kebahagiaan sebanyak mungkin bagi orang banyak.

Meskipun demikian, teori utilitis ini dianggap sebagai teori berat sebelah, karena lebih bersifat subyektif, relatif dan individual.

14 Dalam era pasar bebas dewasa ini, keadilan protektif telah diterobos dengan kesepakatan yang didasarkan pada kompetisi, seperti WTO, APEC, AFTA dan NAFTA yang semuanya memarginalkan golongan ekonomi lemah, sehingga ia tidak bisa lagi dilindungi dari para kaum kapitalis.

${ }^{15}$ Mochtar Kusumaatmadja \& Arief Sidharta,

Pengantar Ilmu Hukum Suatu Pengenalan Pertama Ruang Lingkup Berlakunya ilmu Hukum, Alumni, Bandung, 2000, halaman 52.

${ }^{16}$ Dudu Duswara Machmudin, Op., cit., halaman 26-27. Lihat juga Esmi Warasih, Op., cit., halaman 25.
Anggapan seperti itu tepat, jika hukum dilihat dari segi sejauh mana hukum itu dapat mewujudkan keadilan. Apabila ada keinginan untuk mengeluarkan keadilan dari hukum, maka akan timbul asumsi bahwa hukum identik dengan kekuasaan. Pada hal antara hukum dengan kekuasaan saling membutuhkan sebagai mana dinyatakan Mochtar Kusumaatmadja bahwa "hukum tanpa kekuasaan adalah angan-angan, kekuasaan tanpa hukum adalah kelaliman".

Dari kedua teori yang berkaitan dengan tujuan hukum terlihat bahwa kedua teori tersebut berat sebelah. Seperti terlihat dari akibat mengagung-agungkan keadilan, maka teori etis mengabaikan kepastian hukum. Apabila kepastian hukum diabaikan, maka ketertiban akan terganggu. Pada hal justru dengan ketertiban, keadilan dapat terwujud dengan baik. dan sebaliknya akibat mengagung-agungkan kemanfaatan, teori utilitis mengabaikan keadilan. Pada hal dengan hukum akan bermanfaat, apabila sebanyak mungkin menegakkan keadilan.

\section{Teori Campuran}

Bertitik tolak atas kelemahan kedua teori ini, lahirlah teori ketiga yang disebut "Teori Campuran". Teori ini menegaskan bahwa tujuan pokok dari hukum adalah ketertiban, dan oleh karena itu ketertiban merupakan syarat bagi adanya suatu masyarakat yang teratur. Di antara penganut teori campuran ini adalah L.j. van Apeldoorn menegaskan bahwa pada dasarnya hukum bertujuan untuk mengatur pergaulan hidup manusia secara damai. Soebekti sendiri menyatakan bahwa hukum itu mengabdi kepada tujuan negara untuk mendatangkan kemakmuran dan kebahagiaan bagi rakyatnya. Pada sisi lain Purnadi Purbacaraka dan Soerjono Soekanto berpendapat bahwa tujuan hukum adalah demi kedamaian hidup antara pribadi yang meliputi ketertiban ekstern antara pribadi dan

Hukum Sebagai Sistem. . . 5 
ketenangan intern pribadi. ${ }^{17}$

Terlepas dari ketiga teori yang telah mencoba memberikan pencerahan tentang tujuan dasar dari hukum, namun ketiga teori tersebut tetap belum mampu menjelaskan secara komprehensif tentang tujuan hukum itu sendiri. Oleh karena itu cukup menarik bila kita merujuk pada pandangan Gustav Radbruch yang menegaskan bahwa tujuan hukum itu terfokus pada 3 (tiga) hal yaitu; keadilan, kemanfaatan dan kepastian. Sebenarnya tujuan hukum yang dimaksud oleh Radbruch ini sendiri termasuk pada kategori teori campuran antara teori etis dan teori utilitas yang dikemas dalam konteks hukum modern. Perlu dipahami juga bahwa ketiga tujuan hukum dimaksud dalam penerapannya mengacu pada "asas prioritas", sebagaimana diketahui masing-masing hukum itu mempunyai tujuan spesifik. Antara hukum formil dengan hukum materil tujuannya jelas tidak sama, oleh karena itu asas prioritaslah yang dapat kita lihat sebagai rujukannya. ${ }^{18} \mathrm{Namun}$ demikian, setiap tujuan dari hukum harus mengutamakan keadilan sebagai prioritas utamanya.

\section{FUNGSI HUKUM}

Manusia sebagai makhluk sosial barang tentu mempunyai kehendak. Kadang kala kehendak tersebut tidak selalu sama, malahan cenderung berbeda atau berlawanan sama sekali. Malahan pada sisi lain pemenuhan kehendak tersebut, tergantung juga pada orang lain. Menghadapi kenyataan tersebut, sudah tentu dibutuhkan suatu aturan untuk menata pemenuhan kehendak dan interaksi sesama anggota masyarakat (ibi ius, ibi sociates). Berkaitan hal tersebut, Hobel menegaskan 4 (empat) fungsi dasar dari hukum, yaitu $:^{19}$

1. Menetapkan hubungan-hubungan antara

\footnotetext{
17 Esmi Warasih, Ibid., halaman 25.

18 Achmad Ali, Op., cit., halaman83-84.
}

para anggota masyarakat, dengan menunjukkan jenis-jenis tingkah laku yang diperkenankan dan apa pula yang dilarang;

2. Menentukan pembagian kekuasaan dan merinci siap saja yang boleh melaksanakan paksaan serta siapakah yang harus mentaatinya dan sekaligus memilihkan sanksi-sanksi yang tepat dan efektif;

3. Menyelesaikan sengketa;

4. Memelihara kemampuan masyarakat untuk menyesuaikan dari dengan kondisi-kondisi kehidupan yang berubah, yaitu dengan cara merumuskan kembali hubungan esensial antara anggota-anggota masyarakat.

Pada sisi lain kita juga melihat bahwa hukum berfungsi sebagai kontrol sosial, dalam hal ini hukum harus dijadikan sebagai sarana memperlancar proses interaksi sosial. Hal ini sejalan dengan apa yang diungkapkan oleh Parsons bahwa fungsi utama suatu sistem hukum bersifat integratif. Dengan kata lain bahwa hukum berusaha mengurangi unsurunsur konflik yang potensial dalam masyarakat, dan untuk melicinkan proses pergaulan sosial. ${ }^{20}$

Perlu dipahami juga bicara tentang keadilan dalam institusi sosial, kita dihadapkan pada struktur masyarakat yang bersangkutan. Masyarakat dengan struktur yang sederhana, dalam arti kata secara kuantitas jumlahnya masih kecil, maka interaksi sosialnya sangat erat yang didasarkan pada asas kekerabatan. Dengan demikian implementasi keadilan lebih mudah. Hart menyebut tata hukum seperti ini dengan "primary rules of obligation". Kelemahan tata hukum seperti ini terletak pada "ketidakpastian", karena peraturannya tidak didasarkan pada suatu sistem, peraturan

\footnotetext{
${ }^{19}$ Esmi Warasih, Lot., cit, halaman 26-27. Lebih lanjut lihat Edwin M. Schur, Law and Society, A Sociology View, New York : Random House, 1968, halaman 79-82.

${ }^{20}$ Ibid., halaman 27.
} 
bersifat statis dan cara mempertahankannya tidak efisien. Sebaliknya apa yang dinyatakan Satjipto Rahardjo, di mana dalam masyarakat yang sudah semakin kompleks, tidak cukup dengan tatanan hukum primer (primary rules), melainkan harus ditambah dengan kewajiban sekunder (secondary rules) seperti pengakuan terhadap norma tertentu (rules of recognition), peraturan tentang perubahan-perubahan (rules of change) dan peraturan tentang penyelesaian sengketa (rules of adjudication). ${ }^{21}$

\section{HUKUM SEBAGAI SISTEM NORMA}

Sebelum mengupas hukum sebagai suatu sistem norma, perlu kiranya di pahami lebih dahulu, apa yang dimaksud dengan norma itu sendiri. Menurut Hans Kelsen sebagai mana dikutip Soerjono Soekanto menyatakan bahwa norma adalah "That something ougth to happen, especially that a human being ought be have in a specific wah". ${ }^{22} \mathrm{Jadi}$ secara sederhana norma dapat digambarkan sebagai aturan tingkah laku; sesuatu yang seharusnya atau sesuatu yang seharusnya dilakukan oleh manusia dalam keadaan tertentu. Bahkan ada pula yang menyatakan norma sebagai petunjuk hidup yang mengikat. ${ }^{23}$

Mengingat norma sebagai tuntunan bagaimana seharusnya manusia bertingkah laku dan sekaligus sebagai petunjuk hidup yang mengikat, maka norma tersebut dapat dibedakan atas 4 (empat) yaitu, norma agama yang bersumber dari Tuhan, norma kesusilaan/ moral yang bersumber pada diri sendiri, norma kesopanan yang bersumber dari masyarakat dan norma hukum yang bersumber pada manusia melalui perwakilannya pada lembaga yang mempunyai otoritas tertentu. Sedangkan hukum

21 Ibid., halaman 28.

${ }^{22}$ Soerjono Soekanto, Kesadaran Hukum dan Kepatuhan Hukum, Rajawali Press, Jakarta, 1982, halaman 31 .

23 Achmad Ali, Op., cit., halaman 38. sebagai suatu norma hanyalah subbagian dari norma dalam arti umum. Oleh karena itu kalau bicara mengenai hukum sebagai suatu sistem, berarti kita berbicara tentang hukum sebagai suatu sistem norma.

Permasalahan berikutnya adalah apa yang dimaksud dengan sistem itu sendiri? Menurut Tatang M.Amirin, sistem itu mempunyai banyak makna di antaranya adalah bahwa "sistem menunjukkan himpunan gagasan (ide) yang tersusun, terorganisasikan, prinsip, doktrin, hukum dan sebagainya yang membentuk satu kesatuan yang logis dan dikenal sebagai isi buah pikiran filsafat tertentu". ${ }^{24}$ Dan juga harus diperhatikan bahwa sistem itu sendiri mempunyai ciri-ciri sebagai berikut $:^{25}$

1. Sistem itu bersifat terbuka, atau pada umumnya bersifat terbuka. Suatu sistem dikatakan terbuka jika berinteraksi dengan lingkungannya. Dan sebaliknya, dikatakan tertutup jika mengisolasikan diri dari pengaruh apa pun;

2. Sistem terdiri dari dua atau lebih sub-sistem dan setiap sub-sistem terdiri lagi dari subsistem yang lebih kecil dan begitu seterusnya;

3. Sub-sistem itu saling bergantung satu sama lain dan saling memerlukan;

4. Sistem mempunyai kemampuan untuk mengatur diri sendiri (self regulation);

5. Sistem memiliki tujuan dan sasaran.

Sedangkan pada sisi lainnya, menurut Bertalanffy menegaskan bahwa sistem mengandung implikasi yang sangat berarti terhadap hukum, terutama berkaitan dengan aspek; (1) keintegrasian, (2) keteraturan, (3) keutuhan, (4) keteorganisasian, (5) keterhubungan komponen satu sama lain, dan

${ }^{24}$ Tatang $M$. Amirin, Pokok-pokok Teori Sistem, Rajagrafindo Persada, Jakarta, 1996, hal. 7.

25 Elias M. Awad, System Analysis and desing, Richard D. Irwin, Homewood, Illionis, 1979, halaman 5-8.

Hukum Sebagai Sistem. . I 7 
(6) ketergantungan komponen satu sama lain. ${ }^{26}$

Berkaitan dengan hukum sebagai suatu sistem di mana Lawrence M. Friedman menegaskan bahwa hukum merupakan gabungan dari 3 (tiga) komponen yaitu : $:^{27}$

a. Struktur yaitu berkaitan dengan kelembagaan yang disitakan oleh sistem hukum itu dengan berbagai macam fungsi dalam rangka mendukung bekerjanya sistem tersebut;

b. Substansi yaitu sebagai out put dari sistem hukum, berupa peraturan-peraturan, keputusan-keputusan yang digunakan baik oleh pihak yang mengatur maupun yang diatur, dan ;

c. Kultur yaitu terdiri dari nilai-nilai dan sikapsikap yang mempengaruhi bekerjanya hukum.

Kemudian Lon L. Fuller juga menyatakan bahwa untuk mengenal hukum sebagai suatu sistem, maka harus dicermati apakah ia memenuhi 8 (delapan) asas atau principle of legality yaitu sebagai berikut $:^{28}$

a. Sistem hukum harus mengandung peraturanperaturan dalam arti tidak boleh mengandung sekedar keputusan-keputusan yang bersifat ad hoc;

b. Peraturan-peraturan yang telah dibuat itu harus diumumkan;

c. Peraturan tidak boleh berlaku surut, sebab

${ }^{26}$ Dalam Esmi Warasih, Op., cit., halaman 29. Lebih lanjut lihat Ludwing von Bertalanffy, General System Theory, Foundation Development Application,Penguin Boks, Midlesex, 1971, halaman 91.

${ }^{27}$ Dalam Esmi Warasih, Ibid., halaman 30. Lebih lanjut lihat Lawrence $M$. Friedman, The Legal System : A Social Science Perspective, New York : Russel Sage Foundation, 1986, halaman 17.

${ }^{28}$ Dalam Esmi Warasih, Ibid., halaman 31. Lebih lanjut lihat Lon L. Fuller, The Morality of Law, Revision edison, New Haven \& London: Yale University Press, 1971 , halaman 38-39. apabila ada peraturan yang demikian maka peraturan tersebut tidak dapat dipakai sebagai pedoman bersikap tindak;

d. Peraturan-peraturan disusun dalam rumusan yang bisa dimengerti;

e. Peraturan-peraturan tidak boleh mengandung tuntutan yang melebihi apa yang dapat dilakukan;

f. Peraturan tidak boleh sering berubah-ubah, apabila hal ini sering dilakukan orang akan kehilangan orientasi;

g. Harus ada kecocokan antara peraturan yang diundangkan dengan pelaksanaan seharihari.

Lain lagi pendapat Hans Kelsan di mana sistem hukum itu merupakan suatu pertanggaan kaidah hukum secara perandal. Artinya suatu kaidah hukum yang tingkatannya lebih rendah harus mempunyai dasar atau pegangan pada kaidah hukum yang lebih tinggi tingkatannya. Kaidah hukum yang paling tinggi dinamakan konstitusi dan bersumberkan pada norma dasar yang disebut "grundnorm" atau "basic norm". Hans Kelsen menyatakan bahwa "basic norm's as the source of validity and as the source of unit legal system". Teori ini dikenal dengan Teori Piramidal, Dtufen Theory atau Stufenbau des Rechts. ${ }^{29}$ Sebenarnya teori ini buat pertama kali dicetuskan oleh Adolf Merkl, hanya Hans Kelsen-lah yang mempopulerkannya. ${ }^{30}$ Agar keberadaan hukum sebagai suatu sistem tetap dapat dipertahankan, maka ia harus mampu mewujudkan tingkat kegunaan (efficaces) secara minimum. Efficaces suatu norma ini dapat terwujud apabila : $:^{31}$

2: Lebih lanjut lihat Esmi Warasih, Ibid,, halaman 31-33. Lihat juga Dudu Duswara Machmudin, Op., cit., Refika, Bandung, 2000, halaman 75.

3o Dudu Duswara Machmudin, Ibid., halaman 75.

31 Esmi Warasih, Lot., cit, halaman 33 
1. Ketaatan warga dipandang sebagai suatu kewajiban yang dipaksakan oleh norma;

2. Perlu adanya persyaratan berupa sanksi yang diberikan oleh norma.

Mengingat hukum sebagai suatu norma, diharapkan ia akan menuntun manusia dalam bersikap, bertindak dan berperi laku yang kesemua itu dituangkan dalam suatu sistem hukum. Dalam pembuatan hukum tersebut, kita harus mengacu pada asas hukum yaitu hukum yang lebih rendah harus mengacu pada hukum yang lebih tinggi, dan hukum yang lebih tinggi itu sendiri adalah norma dasar (grundnorm).

\section{PENUTUP}

Para ahli dalam merumuskan pengertian hukum amat tergantung dari sudut pandang dan paham yang mereka anut, sehingga sulit untuk dapat merumuskan suatu pengertian hukum yang memuaskan, atau tidak akan pernah bisa sama sekali, karena hukum itu begitu luas dan banyak segi kehidupan yang diaturnya. Kenyataan seperti ini juga kita temukan pada saat kita bicara tentang tujuan hukum. Karena hukum itu tidak hanya bisa kita lihat dari segi keadilan dan kemanfaatannya saja, tetapi bagaimana dengan kepastian dari hukum itu sendiri. Berdasarkan hal tersebut, dalam implementasi tujuan hukum itu mengacu pada "asas prioritas", sebagaimana diketahui masing-masing hukum itu mempunyai tujuan spesifik. Antara hukum formil dengan hukum materiil tujuannya jelas tidak sama, oleh karena itu asas prioritaslah yang dapat dijadikan sebagai rujukannya, dengan mengedepankan keadilan sebagai prioritas utamanya.

Begitu pula halnya dengan fungsi hukum, mau tidak mau kita harus merujuk pada keadilan dalam arti institusi sosial, kita dihadapkan pada struktur masyarakat yang bersangkutan. Masyarakat dengan struktur yang sederhana interaksi sosialnya cukup didasarkan pada asas kekerabatan yang mengacu pada "primary rules of obligation". Sebaliknya pada masyarakat yang sudah semakin kompleks, tidak cukup dengan primary rules, melainkan harus ditambah dengan kewajiban sekunder (secondary rules) seperti pengakuan terhadap norma tertentu (rules of recognition), peraturan tentang perubahan-perubahan (rules of change) dan peraturan tentang penyelesaian sengketa (rules of adjudication).

Bertitik tolak dari hal tersebut di atas, maka bicara mengenai hukum sebagai suatu sistem, berarti kita berbicara tentang hukum sebagai suatu sistem norma. Sebagai sistem norma, maka dalam pembuatan hukum positif harus tunduk pada norma yang lebih tinggi. Dengan kata lain sistem hukum merupakan suatu pertanggaan kaidah hukum secara piramidal. Artinya suatu kaidah hukum yang tingkatannya lebih rendah harus mempunyai dasar atau pegangan pada kaidah hukum yang lebih tinggi tingkatannya yaitu "grundnorm" atau "basic norm". Diharapkan dengan mengacu pada hukum sebagai suatu sistem norma, maka hukum positif itu akan fungsional alam kehidupan masyarakat.

\section{$-000-$}




\section{Daftar Kepustakaan}

Achmad Ali, Menguak Tabir Hukum (Suatu Kajian Filosofis dan Sosiologis). Toko Gunung Agung, Jakarta, 2002;

Curzon, L.B, Jurisprudence, M \& E Handbook, 1979;

Dudu Duswara Machmudin, Pengantar Ilmu Hukum, Sebuah Sketsa, Refika, Bandung, 2000;

Edwin M. Schur, Law and Society, A Sociology View, New York : Random House, 1968;

Esmi Warasi, "Pranata Hukum" Sebuah Telaah Sosiologis, Editor Korolus Kopong Medan dan Mahmutarom HR, Suryandaru Utama, Semarang, 2005;

Elias M. Awad, System Analysis and desing, Richard D. Irwin, Homewood, Illionis, 1979;

Hans Kelsen, Pure Theory of Law, Berkely: University California Press 1978;

Lawrence M. Friedman, The Legal System : A Social Science Perspective, New York : Russel Sage Foundation, 1986;

Lon L. Fuller, The Morality of Law, Revision edison, New Haven \& London: Yale University Press, 1971;

Ludwing von Bertalanffy, General System Theory, Foundation Development Application, Penguin Boks, Midlesex, 1971;

Mochtar Kusumaatmadja \& Arief Sidharta, Pengantar Ilmu Hukum Suatu Pengenalan Pertama Ruang Lingkup Berlakunya ilmu Hukum, Alumni, Bandung, 2000;

R. Otje Salman, Ikhtisar Filsafat Hukum. Armico, Bandung 1987;

Sudikno Mertokusumo, Mengenal Hukum Suatu Pengatar, Liberti, Yogyakarta, 1968;

Satjipto Rahardjo, Ilmu Hukum, Alumni, Bandung, 1986;

Sjachran Basah, Tiga Tulisan tentang Hukum, Armico, Bandung, 1986;

Soerjono Soekanto, Kesadaran Hukum dan Kepatuhan Hukum, Rajawali Press, Jakarta, 1982;

Tatang M. Amirin, Pokok-pokok Teori Sistem, Rajagrafindo Persada, Jakarta, 1996;

Van Apeldorn, Pengantar Ilmu Hukum, Jakarta, 1983. 